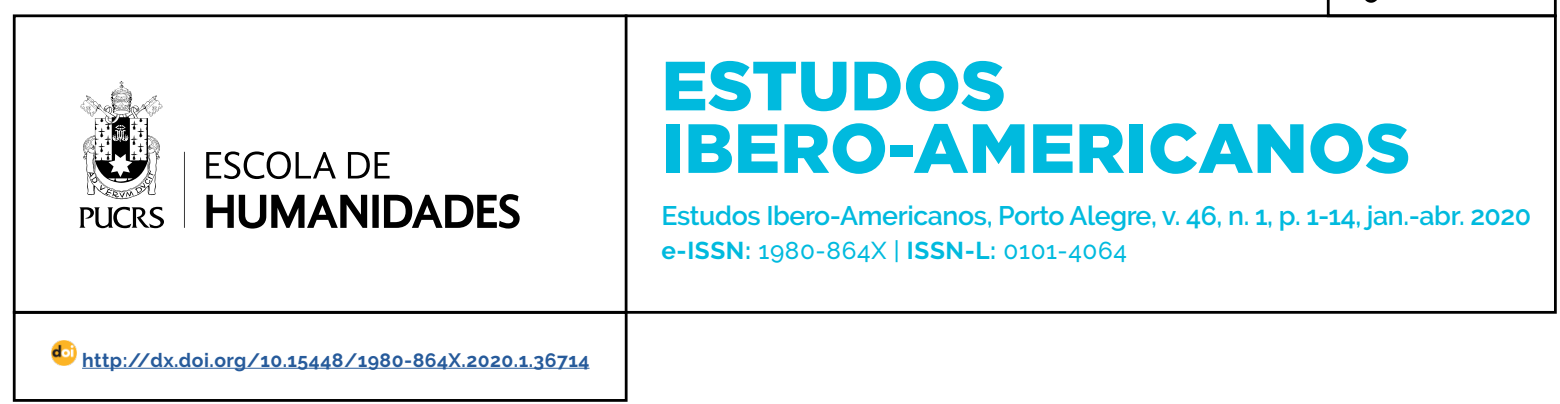

ENTREVISTA

\title{
"A world of connections and changes": the Trajectory of an Environmental Historian in Latin America - Interview with John Soluri
}

"Um mundo de conexões e mudanças": a trajetória de um historiador ambiental na América Latina- entrevista com John Soluri

"Un mundo de conexiones y cambios": la trayectoria de un historiador ambiental en America Latina - entrevista con John Soluri

\section{Luciana Murari ${ }^{1}$}

orcid.org/0000-0003-1517-1016

luciana.murari@pucrs.br

\section{Georg Fischer ${ }^{2}$}

orcid.org/0000-0003-4791-5884

fischer@cas.au.dk

Recebido em: 12 dez. 2019. Aprovado em: $30 \mathrm{dez} .2019$ Publicado em: 28 abr. 2020.
John Soluri, associate professor and director of global studies at Carnegie Mellon University, Pittsburgh, United States, is one of the most innovative researchers in Latin American environmental history. His most well-known work, Banana Cultures: Agriculture, Consumption, and Environmental Change in Honduras and the United States (SOLURI, 2005a), intertwined social, ecological and economic dimensions to study how the tropical fruit became such a widespread product in the American market. Understanding industrial agriculture as shaped by human and natural factors, Soluri showed how turning the banana into a commodity for mass consumption and guaranteeing its steady supply involved dynamic relationships between forests, land, plant varieties, capital, workers, political actors and pathogens. Soluri kept his interest in commodification and environmental change, along with subjects like food security, cultures of consumption and agrobiodiversity. His current research deals with the relationship between humans and animals in Patagonia and Tierra del Fuego in the nineteenth and twentieth centuries. One of the founders of SOLCHA (Sociedad Latinoamericana y Caribeña de Historia Ambiental), he is also a board member of Building New Hope, a non-governmental organization based in Pittsburgh and Nicaragua, engaged in education and support for small rural producers in Central America.

This interview was granted to Luciana Murari and Georg Fischer during the III World Congress of Environmental History, held in Florianópolis, on the $25^{\text {th }}$ July, 2019.

\section{(c) (1)}

Artigo está licenciado sob forma de uma licença Creative Commons Atribuição 4.0 Internacional. 
L.M. For a start, we would like you to tell us about how you became an environmental historian of Latin America: Why Latin America, why environmental history and what did it mean to you at that time?

Well, thank you very much for interviewing me. I am delighted to be here in Brazil for the second time and talking about environmental history with a great group of colleagues. My interest in environmental history started when I was in college as an undergraduate student, and a lot of it came from a course taught by Richard Tucker, who is also at this world congress, in the late 1987. He started a course called "Environmental History of the Tropical World", something like that, and I had the good fortune to enroll in that class. It was a very exciting class. I still remember there were graduate students in it, there were undergraduates in it, and people from all over the world participated. That introduced me to the idea of environmental history.

Similarly, I became interested in Latin America at the University of Michigan. This is a bit of an anecdote: I was taking a history course called Philosophy of the Enlightment taught by an older professor whose teaching style was like: "What does such and such say on page 22 or page 105?" I was terrified, so I went running back to my advisor and said I needed a different history class. And he said: "Why don't you try this course in Latin American history?" So I took that course with a very dynamic scholar, Rebecca Scott. She actually is known in Brazil as she has done work on post-emancipation societies. She got me very interested in Latin America. That is the intellectual context. Then, because in the 1980s, there was so much conflict going on in Central America, and, of course, the United States government was so deeply involved, I also became aware of the political level. Simultaneously, there was a lot of discussion at that time about tropical deforestation in Brazil, the Amazon, Central America, so those things started all coming together for me, and I decided I wanted to learn more about those fields. I had studied a little bit of Spanish, I had no particular background, no family background in
Latin America; Central America was just a pressing issue, it caught my attention. The other thing I would add is that I also was interested in the sciences, and although I was probably better in the humanities. I had that sense that people in the sciences were not deeply contextualizing their approaches, so they were thinking about solutions, things like parks and protected areas. It seemed to me they were lacking the cultural, historical and social context, so I decided to focus on that. Environmental history worked very well for me because it combined those things.

After graduating I quickly realized that it was hard to get a job working in Latin American environmental stuff, so I worked for a local nonprofit organization focused on environmental issues in the place where I grew up, which is New York state, closer to Canada than to Mexico. Then I had an opportunity through luck: a friend of a family who had a grant to Argentina said to me: "if you want an opportunity to go and work on environmental planning projects in Argentina, you can do that". But the catch was I had to be registered in graduate school, and I very quickly applied to some MA programs thinking I was just going to do an MA in environmental policy or environmental studies. Then, one of my old advisors from my undergraduate days said: "Well, why don't you apply for a PhD program, just in case?" I said: "I will do that," so I applied, went to argentina, worked on my Spanish, and then got admitted into the program. I came back and started a doctoral program and a master's program.

Since the 1990s there was certainly the feeling that environmental history started to flourish in the U.S. and in Europe as well, a couple of important books were published in English, for instance by Elinor Melville about Mexico (MELVILLE, 1994) and a little bit later by Warren Dean, who did his master work on Brazil (DEAN, 1996). But there was not a lot. At the time a very important history program like the one at the University of Michigan did not have a full-time environmental historian. For example, Richard Tucker was teaching this very popular course for fun, since he was actually at another local university. I was lucky that Richard was there 
for the intellectual stimulation. But of the people I worked with, nobody did environmental history, the sociologists did political economy or gender, everything but environmental history at that time. In that sense, I had to find my own way. I was very fortunate that being at the University of Michigan I got to know a couple of faculty who were in biology and at the time used a totally new word, agroecology. Agroecology was emerging, and they were very open. I was lucky they were interested not only in agroecology: People trained in biology are very open to working with social scientists and historians. And they were very committed, they were in Nicaragua, in particular in the period of the sandinistas, so they understood my interest in politics and society. They proved to be really helpful, because they introduced me to agroecology. You could say that I got a fairly traditional training in Latin American history from the history department, but then I was fortunate to work more informally with this faculty in agroecology, and I started to think about how to put them together.

When I ended graduate school, I thought I might do the project that I am actually working on now, an environmental history of Patagonia, where I had spent some time. However, I had done some work on the history of the banana industry and I got pulled back into Central America again. Partly still because of the political situation, I was feeling there was a need to be doing work there. First, I did a field course in agroecology in Costa Rica, and I delved into the archives. Looking a little bit around I saw there were quite a few U.S. scholars working in Costa Rica, whereas Honduras had been on the margins, because in the U.S. people can't tell Honduras apart from Costa Rica on a map. But even among the more progressive scholars who I was hanging out with, Nicaragua got a lot of attention, El Salvador, Guatemala were getting a lot more attention because either people were maybe slightly romanticizing the revolution or they were rightfully condemning human rights violations. But Honduras was a country that was seen as the backyard of the United States. There was no revolutionary movement, just U.S. military bases. So, I said yes, I wanted to get to know
Honduras, because nobody is really paying attention to it except for the $\mathrm{ClA}$, missionaries and the Peace Corps. And, indeed, when I was first there, as a young guy, Hondurans would say "Cuerpo de Paz?" or "Missionary?" And l'd say no, no. Then I think they thought "this guy is in the CIA", because that was their frame of gringos, basically people in the military or missionaries or Peace Corps, but not a lot of researchers.

Then I got interested in the banana industry. On the one hand, there was nobody explicitly writing about environmental history in that way. There were certainly some other scholars who, like William Durham, at the time they were approaching human ecology and were studying issues of land, but did not necessarily focus as much on some other themes that today environmental historians focus on. They were very much preoccupied with land, natural resources and society, so almost like an incipient political ecology, although they did not use that name. On the other hand, I started to read some of the older texts, including some from the 1930 s written in English. In one of the first critical works of banana history, the authors pretty much laid out a lot of the themes I ended up exploring in my book (KEPNER, SOOTHILL, 1935). They studied things like costs of the corporate take-over of banana production as well as the marketing and distribution. But there is also this one chapter titled "Banana Graveyards" - and this is a book from 1935 - in which they referred to the fact that the companies were abandoning fields, abandoning farms, moving out and cutting down more forest and replanting. Hence, they alluded to the banana diseases, things that I explore a lot in Banana Cultures. Again, the book at that time was more focused on social and political issues, they just noted that this was happening and didn't really tried to explain it or focus on it. It is important to note that in some ways we as historians write for our own moment, the moment in which we live. Frankly, climate change wasn't really on my radar when I was finishing this project. It was all about tropical deforestation. Of course, these issues are related, but the framework was different. 
In my dissertation that later became the book Banana Cultures, I set out with two questions: First, could we figure out how much land had been deforested in the name of banana plantations? Second, what were the impacts of that deforestation on workers? I was interested in workers, partly because of my graduate formation, but also because I had the sense at the time - I don't know how true it was - that most environmental historians in the U.S. saw a close relationship between native Americans, indigenous groups and the environment. There had been a little bit less done on people who didn't necessarily identify as indigenous but were rather, say, working class. I decided, at some expense of issues of racial identity, to focus mostly on workers and the actual work process. I wanted to know what they were exposed to by way of pesticides, agrochemicals, but also diseases. I was basically interested in the living environment of workers. Not surprisingly, my questions changed in a couple of ways: First, I realized that it was actually extremely difficult to calculate the deforestation rate. However, this revealed to me the dynamism of the banana industry and the idea of a plantation complex which I realized was much more dynamic then I thought, geographically, spatially, ecologically. I started to realize the significance of diseases and, drawing on agroecology, I started to read some literature and think about monocultures, density of planting, things that people are now increasingly familiar with in environmental history, and how that kind of agricultural system can facilitate and promote the spread of plant diseases, pathogens, insects, herbivores or pests. That became more part of the story then. It also helped me to focus on workers and to pay attention not just in the growing in harvesting, but some of the early uses of agrochemicals to control various banana pathogens. Just one example: In the 1930s, before the development of things like DDT, the banana industry started to use a fairly common orchard copper-based fungicide known as "caldo Bordelés". I just worked on some of the health impacts of that. It is worth noting that simultaneously there was another scholar, Steve Marquardt, who actually worked for labor unions in the United States. In a fascinating way, we came from different angles, but we both arrived at the exactly the same sources and told some of the same stories. He was working on Costa Rica. He has some really fine articles that tell a very similar kind of story. As a graduate student, this was unsettling, of course, but now in retrospect it is very reaffirming, because it is actually as close as to historians get to replicating research.

When I started to turn the dissertation into a book, I started thinking about consumption. Some of that I was led to from the sources as I was researching about panama disease, which is this fungal disease that still today circulates in the news and is a great source of concern globally for everybody who grows bananas commercially. I started delving into scientific work from the early twentieth century, and I realized that people quickly realized they needed to find another variety of banana that is resistant and acceptable in the U.S. marketplace, has a similar flavor, similar ripening qualities, similar color. I started to become really interested in this question, the aesthetics, thinking about bananas as food and not just as a commodity, not just as symbol of exploitation, symbol of imperialism, maybe as a symbol of wealth in some cases. But actually, what did it mean to be somebody in the United States eating bananas in the late nineteenth and early twentieth centuries? Why did they start eating so many bananas so quickly? Clearly the low price is important, but what else influenced that? I think that had a little bit of an impact beyond my immediate field of studies. It helped to bring more of a cultural history perspective into the environmental history perspective, which some other people have turned on too, and a more traditional social history focused on workers. The part I was satisfied about of what became the book Banana Cultures, was trying to bring all of those together and show that interactivity. That remains for me one of the great challenges: to show those interactions and the connections. Right now, I think these things are all changing, 
but how can we argue: "Why does it matter? This cultural phenomenon is happening, but how is that really affecting somebody that lives far away?" We are in a world of connections and change, but can we try as historians to show which ones really matter, and why at a certain time?

When I finished that project around 2005. certainly by then environmental history was starting to grow and become more important. Things in Central America changed a lot, and I was becoming, quite frankly, more professionalized. I was thinking about some of these questions, how to begin to, as a U.S. scholar, not just write about Latin America, but actually try to be more collaborative and do work with people in Latin America. That is partly what drew me to a meeting, one of the first meetings that explicitly addressed Environmental History, that took place in Santiago de Chile in 2003. I think it was organized by some people from the Universidad de Chile. It was really one of those memorable meetings because it was rather small, only about thirty, thirty-five people or so, and everybody went to everybody's session. Everybody had a sense that something new was happening, that we all really engaged in that. We spent about three days together. That really got me excited to both think about working outside Central America and to get involved in what was going to become SOLCHA, the Society for Latin American Environmental History. By then I started to realize that there were more people in Mexico, in Brazil, in Chile, in Argentina, in Costa Rica starting to do work in environmental history.

\section{G.F. We would like to know more about what came after Banana Cultures and then perhaps turn to the issues of the organization, the spectrum of Environmental History in Latin America as you see it.}

At that time, I took advantage of the time in Chile to reintroduce myself to the project I had started a long time ago in graduate school. It was about my interest in the environmental history of Patagonia. By that point, scholars in Chile and Argentina started to write about Patagonia, more than they had been doing in the nineties. Particularly strong were cultural histories and studies of how Patagonia fit in national imaginaries. In the United States, animal studies were becoming trendy. In the context when I started thinking about Banana Cultures, many people got interested in the consumption part, but also in commodities. I hadn't originally thought it as a commodity history, but it coincided with the time in the United States and Europe there was a slew of books coming out about commodities, so in a way I became part of the subfield of commodity studies. Then I thought about how I could bring this commodity lens to Patagonia. One of the things that are striking about the region in the context of Latin American history is the almost total absence of agriculture, at least in the far south. In a similar way I had looked at plants, I got interested in the processes of commodifying animals, both native animals, like fur seals and guanacos, and domesticated animals, like sheep, dogs and horses. My current research that has been going on for quite a while, hopefully culminating soon, is a project that employs a methodology similar to the one of Banana Cultures. I am trying to follow the commodity from production to consumption, but in the radically different ecological setting of southern Patagonia. In many ways, it is a fairly different political and cultural setting as well. Ironically for me, personally, is also very much a project in ethnohistory. An important part of the history of southern Patagonia is related with the ranching economy. A couple of very infamous and important strikes took place in the early twentieth century. However, from an environmental point of view, the big story was really the displacement and dispossession of the territories of the hunting and foraging groups that inhabited Tierra del Fuego and southern Patagonia right up into the late nineteenth and early twentieth centuries. So I have come around after distancing myself from thinking about environmental indigeneity. However, it is about trying to integrate ethnohistory rather than setting it apart from other histories such as business history and the history of capitalism. We need to tie together how some very particular ranching interests benefited and worked actively to displace indigenous peoples. In some ways it's 
not exactly environmental history per se. For me it is, but other people might not perceive it exactly in that way. I am trying to think about cycles of hunting, the relationships between hunting and herding economies. I'll probably include the rise of tourism and, to some extent, the revalorization of native farmers, still serving economic interests and commodification, but now rather exporting the "farmer" in the attempt of drawing tourists into the region. However, when we write, nothing is as neat as we would like it to be. I'm not entirely convinced the farmer is actually what draws the people. I think that the Patagonian landscape and the imaginary around it probably draw more tourists than the animals per se, but I am still thinking that through.

The tast theme I will mention, and that is again related to bananas, is thinking about ideas of reproduction of organisms. I'm interested in how modern human societies have over time tried to gain increasing control over sites of reproduction of animals. I wrote a brief article a few years back about the salmon industry in Chile, the salmoneras, and in some ways that to me represents the height of technoscience. The entire life cycle is highly, highly controlled, at least they try, strongly directed by business and technoscience (SOLURI, 2010). I have studied commercial hunters going down in very precarious situations and trying in luck to stumble upon a birthplace, a mating ground of fur seals, where the birth site is still critical to the economy, but not very much controlled by people through a herding economy, where increasingly genetics and artificial reproduction are mobilized to breeding. Acquaculture is now maybe the height of this kind of hyper breeding and raising of caged, farmed animals.

That said, I think in the field of environmental history, there are many other exciting areas to research. I am drawn toward energy. Not surprisingly, this is a global convergence. There is an increasing interest in energy production, energy transmission, energy consumption and Latin America is a great place for that to happen. We are starting to see researchers doing work on petroleum, hydropower, biofuels, and the whole development of ethanol, which has a deep history in Brazil. A rich history can be framed around energy issues. It is one area that is ripe for more research. Urbanization is, of course, another process long associated with Latin America, although here I defer to the literature in Portuguese and Spanish. In English, I am always surprised by how few historians have written about urban space, the spatial dimensions of the city. The notion of energy flows or resource consumption tends still to be pretty limited and I think it is starting to change. I am a great example, a poster child, of this strong bias toward agroexport economies. There is a need to, alongside studies of agroexport economies, work on urban histories and urban/hinterland connections. Brazil is a great example, of course, but almost every country in Latin America, certainly in the twentieth century, generated its own internal economies. People like myself, influenced by dependency theory, tended to not really be interested in internal consumption and domestic economies, but I think that is extremely important. Very concretely, I am interested in, say, beans, frijol, feijão, and asking questions like: What is their significance, their cultural history? Who is growing them? What kind of varieties? What has happened with urbanization? In the second half of the twentieth century, we had this rural-urban migration. With it came the rise of supermarkets, the consolidation of production and commercial food chains or networks, but now not to the United States, Europe or China, but from the state of São Paulo to the city of São Paulo, from Minas Gerais to Belo Horizonte. These are important areas on which there is a lot to be done, particularly from the angle of agroecology and biodiversity.

\section{G.F. Do you think that the logics of academic careers hinder research on these kinds of topics, because it is simply sexier to study transregional flows rather than internal markets and agriculture?}

I think you're right. Obviously this is very much projected from the United States and things in the United States are changing. The fortunes in 
humanities are not super strong. I have had the good luck to be at a private university where the emphasis is on research, and basically what that boils down to is financial resources, the possibility to do research and not to have to teach a ton. Adopting transnational and global history perspectives implies for the historian almost inevitably multi-archival research in multiple places, and it also takes a lot of time. I know there are many archives for this project in Patagonia that I am not going to get to, there is no way I am going to do it. I think it does has real implications not just for research between, say, the United States and Brazil, or El Salvador and Honduras, but even within the United States. There are distinct hierarchies, so the number people who realistically can do deep archival dive in transnational history is probably quite limited. That is something the field has to certainly recognize and think about.

We have to remember not to get too caught up in the notion of the global and of everything flowing. I was just teaching a graduate workshop about transnational history in Costa Rica and one of the very simple ways I put it - I was actually borrowing somebody else's idea - is that when we think about flows, we also need the metaphor of what sticks. It is a very simple, not very academic metaphor because things are always flowing, and at some point, at least momentarily, they stick and have a relevance in a particular place at a particular time. That is important because you can find bananas everywhere, Coca Cola is everywhere, you start following sheep, and - guess what? - you realize they are all over the world. We can tell the same story over and over again, which I don't think is going to advance scholarship very much. It won't necessarily advance people who are interested how environmental history can help us rethink the future. We need to stop and say: "Okay, sheep have come to southern Chile, what happened?" Maybe other things passed through and were not so important.

Coming back to the question of the role of the universities, it is important to always recognize not all universities are equal, they vary a lot, and so do people's particular positions. I find it interesting how at a congress like this one the emphasis is on English. It is the language of scholarship, the language people are publishing in. This is understandable and the notion of lingua franca obviously it has some great utility. However, it would be fatal to see it in purely utilitarian terms and to not recognize that there is a cost, to see it as being neutral, which clearly it is not. We need to think about all this in environmental history, because - and people in Latin America think similarly - it really does not make sense to limit environmental history to national borders. I mean, obviously there may be times when the scale needs to be local, regional, when one needs to study national policies and politics. But looking at whatever the issue is, quickly there is at least a transnational or international dimension to it. I can think of scholarship on environmentalism in Brazil and its political elites who were certainly concerned first and foremost about maintaining their power in Brazil. However, they always had a glance toward how the international community was looking at Brazil, at the Brazilian state. In that sense, there is something very compelling about a more-than-nation-state approach to environmental history. It should continue and I hope it will continue, but this does not mean that thinking with a bigger geographical scale somehow becomes more important, that the flow of coffee or soybeans is more important than the movement of a bean from and to a market, wherever that market may be. We have consider all of those things.

L.M. In regional terms poverty is a big question in Latin America. Conservative politicians sometimes use the discourse of poverty as a way to control or to resist environmental policies. How can environmental history help us to cope with the dilemma between economic development and environment protection, poverty and quality of work, for instance. How can we find a way to deal with this debate, which is still very relevant in Latin America?

In Latin America and even increasingly in the United States, we don't use the word "development". 
The region where I am living, West Virginia, which is one of the poorest regions in the United States, has a history remarkably similar in some ways to many parts of Latin America. It was exploited first for its timber, then its coal deposits, and now it suffers from all kinds of issues linked to poverty and drug addiction. It turned to fairly conservative politics, white nationalism. Even though we don't use the word "development", the term just becomes "jobs". I do not want to say it is the same, the challenges for people who are not content with the present trajectories, conditions of poverty and inequality, over-exploitation of resources, are certainly more pressing in places like India, Brazil, Chile, Costa Rica, Honduras than in the United States. But I think there are connections and convergences throughout the Americas.

I don't know if environmental history can offer anything in the following sense: Claudia Leal, José Augusto Pádua and I were thinking of this as we were working on an edited volume recently (SOLURI, LEAL, PÁDUA, 2018). When we were writing the introduction we were, of course, thinking about what to say, what we were writing, for whom we were writing, what was the point of this. Many books, at least in English in the United States, will end with some kind of "I hope this can contribute toward sustainability, toward human rights", and Claudia said: "You know, this book doesn't do anything". She really made me think about it, so we added that reading this book is not going to do anything to reduce lead levels in poor children in La villa inflamable in Buenos Aires, it's not going to help any species, it's not going to help mitigate climate change. It is important to recognize this, because scholarship can hopefully inform. Do we want to think of ourselves as cultural workers? We are citizens, we're are people putting ideas out there, hopefully somebody is thinking about, directly or indirectly, obviously an important work to do, especially to the extent we are saying things that other people don't say or don't try to disseminate. But I do think, and maybe it's very much a U.S. perspective, that it is important, not to confuse professional work and publications for academic journals with political or social change. I mean, there obviously could be connections, but to me they are not at all clear and not very direct. Of course, as intellectuals or academics, we have some influence in society. Environmental history and many other kinds of history that are not just reinforcing a nationalist narrative are imperative right now and we do need to recognize that there are forces that would be very happy to see environmental history go away. Probably the risks are a lot higher in Brazil right now than in the United States. In the United States, we are just going to be dried out. Basically the funding will decrease.

I'll mention a couple of things environmental history can do: We need to avoid romanticizing the past. We don't want to create the "ecological Indian", the noble savage, we don't want to romanticize the campesino or the household farmer. We need to acknowledge, humans transform environments and it's hard not to see the wonder and the beauty in some of those transformations, in developing all the crops, whether it is the cassava, mandioca, maiz, all these things. Of course, this is associated with transformations and maybe some species loss, but they are part of human culture and who we are as humans. That has to be recognized and celebrated in some ways. Environmental history also needs to remember to do that, and increasingly think about the ways that people find joy and pleasure with the more-than-human, not just to think of humanity as destruction. The book by Warren Dean is the quintessential history of declension, which starts with the first wave of humans, continues with the second wave of humans and is all about humans cutting down the forests (DEAN, 1996). That story is important to acknowledge, but it is hard to imagine a future with that kind of a narrative. It is obviously an important book, but then we need to think about what other narratives there are. I think part of history is to avoid determinism and try to go back and see where things were cut up. Creating today's world did not just unfold as a part of human nature, it's the product of lots of struggles, brutality and violence, which is not always fun to 
write and talk about. Obviously, elites and many other people really either want to forget it or don't really want to acknowledge it. It is not so much a question of culpability - in some ways it is, of course -, but it is more about saying: look, the world today with every color of high modernism, high capitalism, big states, it's just not human nature, right? People were forced into it, dragged into it, coerced into it. Again, these very unpleasant histories need to be told, hopefully not just to document victims, but to remind people that there is an alternative.

Environmentalists have to recognize and think about poverty and inequality. Think about the specific case of Venezuela. For a long time certain people in the U.S. left just refused to criticize the regime of Chávez - and this is not a discussion about Hugo Chávez. But the point is that it is a petrostate. There might be fantastic distribution, but at the end of the day it cannot really serve as a model any more than the United States can serve as a model for the world. There is a big question about Venezuela as a petrostate that nobody seems to want to take on: What is Venezuela's future even with chavismo. Where is it fifty years from now? What's the model? And that is where ecology enters to broaden the understanding of people who are correctly concerned about inequality and poverty. This is also true for aspects of "development", public health, food security, roads, transportation, things that have benefited us a lot, but whose real costs we have to acknowledge. We need to find some way to bring these two perspectives together: older sociological models or ecological models that either excluded human nature and population growth or ignored environmental issues and said it's all about politics and social determinism.

To me, the promise of environmental history is to question ecological, biological or social determinism. It's obviously not the only way to get there. Gender studies or studies of feminism opened up a lot of similar questions, obviously in a very different way. I think there are great possibilities to bring those two together. It makes a lot of sense to bring together feminist theory with some environmental theories or environmental history, and yet very few people are writing these studies. That is not just true for Latin America, it's true worldwide. There is something very important intellectually we are missing. I won't speak for other fields, but environmental historians haven't really done a good job of bringing those together. I think there's a lot to be done.

G.F. Now you've mentioned feminist theory and that, of course, brings us to the question of all the other disciplines that are taking on the challenges of studying human/non-human interactions, like more-than-human anthropology or ecocriticism - environmental humanities at large. Where is environmental history in this whole scenario? Have we understood the language that these other people are using? Are we prepared to interact with them? Where do you see the possibilities or challenges?

When we think about environmental history in relationship to other academic disciplines, the most important ones to me are anthropology and increasingly geography. I find myself increasingly turning to geographers, at least to make sense of contemporary globalization processes or spacialization in history, there's a lot to be offered there. Certainly in the United States, environmental humanities is becoming increasingly significant, and from my experience that seems to be translating in the U.S. context into departments of literature, comparative literature, English, some in philosophy as well. I have to admit to have this initial twinge against environmental historians who say environmental humanities seems to appropriate history, maybe other fields. History, at least in the United States, is constantly on the line between the social sciences and the humanities. In Latin America too, sometimes it is in the humanidades, sometimes in the ciencias sociales. Environmental humanities is obviously a welcome development, to the extent that it opens the possibility for greater dialogue across fields. Certainly, literature is a very important part of history. There have been a lot of valuable exchanges between people working in history, in literature or in philosophy. In practical 
terms, people define their research project and if they think a historian has got something to say they are consulted.

It is not clear to me exactly how, at least speaking of the United States, environmental history per se is relating to develop the field of environmental humanities. I don't want to be too cynical. In the United States, with the crunch in the humanities, there has been great interest in environmental issues - with the current administration it is not getting better though - and a recognition that we need to bring humanistic perspectives in. Being a little bit cynical, I think people are getting degrees in English or history or philosophy and wisely position themselves as having relevance for environmental matters, climate change, biodiversity and environmental justice. It maybe helps to make one seem relevant to both getting a job and having a career. I don't want to say that this is what is driving people, but I think the emphasis in creating conferences, workshops and journals gets back to this question, to the way that academia creates great opportunities, but then in some ways also certain constraints.

I should come back two seconds to environmental history in Latin America and the rise of SOLCHA, that now has been in existence for - depending on how you count - fifteen to twenty years, which is fantastic, but things can become, as we say, "clubby". We who have been involved in it for a very long time are aware of this and the leadership is trying to constantly bring new people in. It is very important to reach out to different regions. We now have quite a few Brazilians, Mexicans, Costa Ricans. I don't think we ever had anyone from El Salvador, maybe one or two from Bolivia. Clearly, there are reasons for this, it's not surprising. In the same way like English becomes the lingua franca, you can understand these things, but it doesn't mean you want to accept them. Is this status quo what we want? We need to figure out how to change that.

One thing I like about SOLCHA is that there has been space for people from other disciplines, people working with ecology, occasionally some biologists, geographers, anthropologists. They all more or less feel comfortable. Having history in the name is not always the best. There is also SOCLA ${ }^{3}$, a society for agroecologists that also has meetings. It is a classic academic situation we have a SOCLA and a SOLCHA. I don't think we really know each other exist, or few of us know that. To look at it positively, there are a lot of opportunities emerging for environmental history in Latin America, to not only strengthen itself as a field, but also to reach out to other fields. In that sense, I am maybe very idealistic in how I think about what an intellectual should be. I don't really care if people call me a historian or not, I mean history is important, but what's really important is that people interested in thinking about human-environment relationships have places to come together and share ideas. Whether their approaches are anthropological or sociological, the critical thing is that we find more opportunities to come together and talk. So, yes, SOLCHA is necessary and important to solidify history, but my dream SOLCHA would be one that can go beyond history, can continue to be more porous, more open to other disciplines coming in, constantly reinventing itself, which is probably idealistic, because everybody has limited resources and professional commitments.

\section{L.M. Since environmental history as a field was built in the United States, do you think it should evolve towards a more diverse set of philosophical and historiographical references?}

I certainly like to think that environmental history can be more than just a U.S.-centric field, but it's certainly good to know the challenges. Although we talk a lot and sensibly about divides between, say, environmental history made in the U.S. and environmental history made in Latin America, I'm increasingly astounded and embarrassed by how little contact there is across the Atlantic. There are scholars in Europe who work on Latin America, and I am barely aware of their scholarship. Maybe one feels more pressured

3 Sociedad Científica Latinoamericana de Agroecología. 
to know what is going on in the U.S. scholarship. You could say it is closeminded, but it is also the problem with having too many resources and such a big university system. You can make a career without going outside the boundaries of the U.S. Donald Worster, who is one of the founders of U.S. environmental history and who in the beginning - and I think he would be OK if I say this - was someone I both admired, but also in a sense was trying to write against, because I felt he was so U.S. focused. However, to his credit, when most people would be retiring and just going to the beach, he has reinvented himself. Alright, maybe he does not the need to reinvent himself, but he is now in China a big part of his time, doing much more work, taking risks. That is a great example of how in the U.S. there is finally more communication. There is also another complex that in the United States we don't fully recognize: we are part of the Americas, we share things with the Americas. I worry that as much as we try to talk about breaking out of the Eurocentric framework, most of my models are still undeniably coming from scholars who were born in or who worked in what we understand to be Europe today European society, speaking European languages, writing in European languages. On the one hand, we have unfortunate lack of communication with scholars today, and on the other hand, and I think this is a challenge for all the Americas, we still have an uneasy relationship with Europe.

I was trained, to large extent, with U.S. historians, empiricists with a focus on social history. You did not write a lot of theory into your work. I still find a lot of people who drop references to theories, which I don't particularly like it as a reader. I kind of bury it. I took it as a great compliment when in the preface to the Spanish version of Culturas Bananeras, Alexis De Greiff mentioned that it's very "Latourian". I like Bruno Latour, but here is the thing: the agroecologist who helped me with my thesis first introduced me to Bruno Latour, not a historian. Interestingly enough, he thought much more theoretically and was very interested in critical approaches to science. It was Latour's famous work on how science works, black boxes, computers...
One term I hope you never see me use in printing is "Western", because I find it to be a very problematic term. Scholars in, say, Latin America need not only to be reading what comes out of the United States, but think more horizontally, so to speak, about the work of scholars from India or China or from post-colonial situations like South Africa. There is a lot of interesting work in this whole project of provincializing Europe, and I do feel very grateful for the rise of world history. In spite of being dominated by the English language and having become an industry in the United States as far as teaching in universities is concerned, it was really when I had to teach world history to undergrads that I was forced to start reading a little bit about the Middle East, books like Janet Abu-Lughod's Before European Hegemony, that talks about thirteenth century world circuits (ABULUGHOD, 1989). They don't come up explicitly in what I am writing, but they do help me to frame questions. This means being exposed to at least a little bit to what's going on in other parts of the world, but then also rethinking what means to talk about Europe. You cannot really think about it without at least thinking about Islam, for example, and in the intellectual exchanges that took place. At least for Iberian America these were very important. It is unfortunate that, at least in my reality, a lot of the scholarship is filtered in English and through U.S. academies, but in spite of all this there are some real positive things happening with globalization. A lot of it is hype and needs to be recognized as such, but also it would be wrong to think it is all hype. There is obviously some very important scholarship that is helping us to establish new networks.

I've noticed in some conversations here about the extent to which environmental historians in Brazil are too focused on Brazil and to what extent they should be thinking beyond Brazil. If you are not living and working in the United States, it seems there are a lot of people in the United States who work on non-U.S. topics, but it is very important to remember that there are so many historians in the United States writing about the United States. Really, the vast majority 
of what people in the United States understand as history is U.S. history. The most popular, the most consumed histories continues to be very old and familiar narratives of the U.S. nation. The fact that some people are working outside the U.S. is the exception to the rule, and it's almost like, if you want to be cynical, the crumbs of the empire. People were trained in Latin American history, partly, because the U.S. federal government in the Cold War poured money to create area studies centers. To the extent that there is something positive there is that a lot of people who took that money and went in to do research suddenly realized that modernization theory and Cold War notions of communism were completely wrong. They at least tried to be some voice of dissonance against the more dominant discourses and policies of the U.S. government, and of governments in Latin America and Europe too. In accordance with this constantly is going against the grain, I do think scholars in the U.S., at least in environmental history, are increasingly aware and engaging. You can actually see it in some of the people that come here. Many people here are doing U.S. environmental history, but they are here because they are interested in other stuff. That is a hopeful sign. It is not the dominant trend yet, but I think it is slowly shifting.

G. F. In practical terms: We are here at the WCEH. Although it is not a mega-conference, like any international conference, the meeting has a huge ecological footprint. How can we organize knowledge transfer and global epistemic communities more sustainably in times of climate emergency which has sparked movements like Fridays for Future, Scientists for Future, Extinction Rebellion or \#fyingless?

The question of how an international group of scholars can exchange ideas in a world of climate change being concerned about, as we are, our ecological footprint is important. We also have to acknowledge that at some level we are tourists, we travel. It's not only an ecological question, but also a question about inequality. What makes it affordable to travel is that somebody is there to make our beds, to make our food, to do all the stuff we don't do because we are not living at home. With the real cost of that, few of us would be travelling to conferences. So there are all kinds of issues we need to think about. That said, I think it is way too easy just to say we stop travelling. There is a very long history of people travelling and exchanging ideas, not just coming from Europe or the U.S. It is part of what we do. It is not enough, for those who can afford it, to pay their carbon offset. We need to think creatively about how to organize meetings, maybe mediated with technology. I am a little bit skeptical about it, I don't think it can fully replace physical conferences. It's not just having the resources per se, it is having the people who know how to use the technology.

Within SOLCHA, people have been thinking about how we can organize things. They have created ideas like the escuelas de postgrado to bring students together. As professors we need to think a lot more about diverting our resources to bringing graduate students to us, whether that is in Rio de Janeiro, the United States, wherever it may be. Of course, it's about resources. We bring together students who can meet with just a smaller group of faculty and share their writings. That may be at least as important as having meetings of scholars who are already out of graduate school. But it is a real challenge, we do need to symbolically confront it. In the United States it's a very quick conservative thing to say: "You are an environmental historian and you fly all over the place". It's a very weak argument, but there is the undeniable reality that I am travelling way more than the average global citizen. I have already travelled way and consumed more resources. There is a point in which I imagine that, if we need to restructure economies as a way to get out of fossil fuels, are we going back to maybe taking boats? We need to continue to find ways to exchange across borders and regions, but we do need to think about the social and ecological costs of doing these kinds of academic conferences. I won't speak as much for Latin America, which is a little bit different, 
but in the U.S., we put money into corporate economies: the bigger the conference, the bigger the venue. You meet in big cities and reinforce the dominance of a capital city and we are just becoming consumers to corporate capital. We are trying to, of course, create a counter-discourse, but we have to remember we are still doing it, unfortunately, within increasingly corporatized frameworks - including the spaces. I love meeting in spaces at a public university. It is hard as hell to find the rooms, but I would rather struggle to find a room than, than being - and I think is the model in the U.S. more than anywhere else - in a big hotel or convention center that is about fitting a lot of people in at a relatively low cost. Often it isn't even that low.

\section{M. One last question: do you still think that environmental historians are freaks?}

Yes, I think so. When I suggested environmental historians needed to think about being freaks (SOLURI, 2005b) it was about the hope to somehow break free of established ideologies. Maybe ultimately we're just creating yet another new ideology that at the end of the day only works so far, but a lot of our current ideological frameworks don't seem to be able to solve all the problems to be solved. We need not to be longing for a past one, but thinking differently. I invoked "freak", and this is obviously very much languagespecific, because it's a term that doesn't have, at least according to the linguists, a deep etymology that can be tied to an identity that's associated with nation, race or gender. It can be used in that way, but I was trying to invoke it to think about new forms of identity that don't necessarily built but on older ideas of trying to look to the future, although I don't think we can escape them entirely. I like to think environmental historians can still be a little bit freaky in that sense of the term. I actually think the plenary talk we heard by Brigitte Baptiste started to get to that idea. It's the heterodoxy of environmentalism. That is when we start to destabilize things. It is very unsettling, but I do think it is a functional role that, paradoxically, we, environmental historians, need to play. Not destabilizing just for the sake of destabilizing. We do need to do that, not because we are hoping everybody in the world is going to start think that way or to create some new dominant ideology, but just the opposite, to constantly remind people that what we take to be the world in common sense is deeply specific and particular. There are some risks, let's face it - not so much for me but for many people. They live it. There is real risk, but to be in that freak position is that we have to keep reminding people that the world we live in can be different. It will be different. The question is in what way it's going to be different and how can we try to make it a little better.

\section{References}

ABU-LUGHOD, Janet L. Before European Hegemony: The World System A.D. 1250-1350. New York: Oxford University Press, 1989

DEAN, Warren. A ferro e fogo: a história e a devastação da Mata Atlântica brasileira. Tradução Cid Knipel Moreira. São Paulo: Companhia das Letras, 1996.

KEPNER, Charles D.; SOOTHILL, Jay H. The Banana Empire: A Case Study of Economic Imperialism. New York: The Vanguard Press, 1935

MARQUARDT, Steve. "Green Havoc": Panama Disease, Environmental Change, and Labor Process in the Central American Banana Industry. American Historical Review, [S. l.], v. 106, n. 1, p. 49-80. 2001

MARQUARDT, Steve. Pesticides, Parakeets, and Unions in the Costa Rican Banana Industry, 19381962. Latin American Research Review, IS. L.], v. 37. n. 2 , p. 3-36, 2002. https://doi.org/10.2307/2652224

MELVILLE, Elinor G. K. A Plague of Sheep: Environmental Consequences of the Conquest of Mexico. Cambridge: Cambridge University Press, 1994. https://doi.org/10.1017/CBO9780511571091

SOLURI, John. Banana Cultures. Agriculture, Consumption, and Environmental Change in Honduras and the United States. Austin: University of Texas Press, $2005 a$

SOLURI, John. Something Fishy: Chile's Blue Revolution, Commodity Diseases, and the Problem of Sustainability. Latin American Research Review, [S. L.], v. 46, n. 2, p. 55-81, 2010. https://doi.org/10.1353/lar.2011.0042

SOLURI, John. Environment Freaks of Nature. Environmental History, [S. L.], v. 10, n. 1, p. 94-95, 2005b.

SOLURI, John, LEAL, Claudia, PÁDUA, José Augusto (org.). A Living Past: Environmental Histories of Modern Latin America. New York: Berghahn, 2018. https://doi.org/10.2307/j.ctvw04gzn 


\section{Luciana Murari}

Doutora em História Social pela Universidade de São

Paulo. Professora da Escola de Humanidades e do Programa de Pós-graduação em História da Pontifícia Universidade Católica do Rio Grande do Sul.

\section{Georg Fischer}

Doutor em História pela Universidade Livre de Berlim. Professor associado da Escola de Cultura e Sociedade da Universidade de Aarhus, Dinamarca.

\section{Mailing address:}

Luciana Murari

Pontificia Universidade Católica do Rio Grande do Sul - Programa de Pós-graduação em História

Avenida Ipiranga, 6681, prédio 8, sala 403.

Partenon 90619-900

Porto Alegre, RS, Brasil.

\section{Georg Fischer}

School of Culture and Society - Aarhus University Jens Chr. Skous Vej 7

Building 1467, 3rd floor

DK-8000 Aarhus C. 